\title{
POLITIK IDENTITAS DI TENGAH DUALISME KULTURAL
}

\author{
Ida Bagus Made Satya Wira Dananjaya
}

\author{
Jurusan Ilmu Administrasi Negara \\ Fakultas Ilmu Sosial dan Ilmu Politik Universitas Mahendradatta \\ J1. Ken Arok No. 12, Peguyangan Denasar \\ E-mail: gus_dananjaya@yahoo.com
}

\begin{abstract}
Abstrak - Identitas merupakan hal yang sangat penting bagi suatu Negara. Identitas tidak pernah diciptakan dalam ruang kosong, identitas tidak hanya terberi tetapi juga menjadi, selalu dikosntruksi, didekonstruksi dan direkonstruksi secara terus menerus tidak berkesudahan, terlebih dijaman global yang juga disebut bersifat dualisme kultural, sehingga identitas juga disebut proyek kebudayaan Tulisan ini menyajikan konstruksi identitas sebagai langkah politis di tengah dualisme kultural.
\end{abstract}

Kata Kunci: Identitas, dualisme kultural, globalisasi.

\section{PENDAHULUAN}

Abad ke-21 yang juga disebut era millenuim atau postmoderin disuguhi oleh gejala globalisasi. Globalisasi merupakan sebuah proses kebudayaan, dimana ada kecenderungan wilayah-wilayah di Dunia dibuat menjadi satu dalam format soisial politik ekonomi (Nugroho, 2001:30). Iklim yang demikian sebagai konsekuensi dari masifnya perkembangan teknologi industri dan komunikasi serta penyebarannya secara massal ke seluruh Dunia. Keterhubungan berskala global dapat mempengaruhi berbagai lini kehidupan masyarakat termasuk prihal identitas suatu negara. Bila dicermati dalam konteks Indonesia, negara yang telah dan tengah membangun serta merumuskan identitas nasional menghadapi suatu kenyataan bahwa: Indonesia sebagai bagian dari dunia global memiliki refrensi lokal dalam merumuskan identitasnya, namun di lain pihak juga sebagai bagian dari jagat global terdapat arus kultural yang menginjeksi Indonesia begitu cepat dan dalam, sehingga menjadi refrensi, konsumsi, bahkan adaptasi bagi perumusan identitas masyarakat.

Ekspansi kultural yang masuk ke Indonesia melalui proses global menyebabkan adanya berbagai penyesuaian dan penyeragaman nilai-nilai yang dianut masyarakat, globalisasi juga telah melemahkan identitas nasional (Martono, 2016:189).
Penyesuaian menurut Giddens (2005) adalah adanya intensifikasi relasi sosial antara lokalitas tertentu dengan yang lain dalam rentang ruang dan waktu berbeda dan saling mempengaruhi. Sedangkan penyeragaman merujuk pada asumsi yang menyatakan kita hidup dalam satu Dunia yang tanpa batas (Giddens, 2005). Berpegang pada gagasan Abdullah (2009:55) Semakin kabur batas-batas fisik dan budaya menciptakan deteritorialisasi, suatu dunia baru dengan batas-batas wilayah dan nilai yang bersifat relatif. Faktual tersebut menegaskan identitas suatu bangsa bersifat dinamis, negosiatif dan dapat dirundingkan. Keniscayaan bahwa bangsa Indonesia secara politik membangun identitas nasional melalui aneka macam gugus pengalaman, nilai-nilai serta kebudayaan lokal, yang dianggap asli serta tradisional, dilain pihak keterbukaan dan cairnya batas-batas wilayah memastikan masuknya nilai-nilai, budaya luar yang dianggap baru, progresif, dan maju menjadikan persoalan identitas tidak hanya pada kategori oposisi biner, antara ke-kitaan dan ke-mereka-an, di tengah kontestasi budaya antara lokal dan global. Proses pembentukan identitas dari luar dikenal dengan proses westernisasi, kebarat-baratan yang sesungguhnya asing bagi masyarakat (Adimihardja, 2008:108). Perumusan identitas semakin pelik karena meruap diruang publik 
dan diwacanakan dalam tema identitas kultural, identitas nasional, identitas kesukuan, identitas kosmopolitan dalam globalisasi dan semacamnya (Putranto, 2016:103).

\section{PEMBAHASAN}

\section{Identitas di Zaman Dualisme Kutural}

Dualisme kultural yang dikemukakan oleh Atmadja (Bali post, 2010:6) berintikan pada ide yang memilah sesuatu menjadi dua hal berdikotomi. Dualisme kultural juga berkonotasi dengan konsep modernitas yaitu mengenai pemikiran oposisi biner. Kecenderungan berfikir oposisi biner akan menempatkan dua hal yang selalu dipertentangkan dan yang pertama dianggap sebagai pusat, prinsip, substansi, asal, sakral dan supreme. Sedangkan yang kedua merupakan kebalikan dari yang pertama, yaitu non-subtansi, manifes, profan, sub-ordinat. Terkait dengan fenomena globalisasi sebagai sebuah gejala dualisme kulturan terdapat kontestasi kutural antara lokal dan global, antara spiritual dan ritual antara yang banal dan substansial.

Faktual mengisyaratkan di lapangan bahwa fenomena dualisme kultural secara nyata telah ada di Indonesia karena terbukanya pintu masuk bagi budaya luar serta kaburnya batas-batas wilayah melalui teknologi informasi. Pada zaman keblingerini (Koesoema, 2009) dimulainya suatu upaya yang massif dari wilayah pusat memasukkan budayanya ke wilayah pinggiran. Wilayah pusat merasa memiliki kebudayaan yang tinggi, maju, progresif, sedangkan wilayah pinggiran dianggap masih kuno, regresif, dan budaya rendah. Dengan adanya kenyataan tersebut wilayah pinggiran harus terus mengupgrade diri untuk memenuhi tuntutan dari wilayah Pusat. Hegemoni budaya wilayah pusat menggariskan kecintaan dan kebutuhan akan kemajuan dan dalam dan esensial, sedangkan yang kuno menjadi barang antik untuk dipajang di museum. Singkatnya tradisionalitas yang masih menjangkiti wilayah pinggiran dianggap sebagai penyakit kronik yang harus ditinggalkan, sedangkan kemajuan budaya tinggi merupakan kebutuhan yang harus dikejar dan ditemukan melalui benda-benda yang diproduksi wilayah pusat sehingga melahirkan fethisism.

\subsection{Pancasila Audensi antara Identitas}

\section{dan Perbedaan}

Identitas selain sebagai suatu bentuk dasar pengenalan terhadap suatu hal, juga merupakan pembentuk solidaritas sosial. Identitas sebagai warga negara menjadi bingkai politik untuk semua orang, terlepas dari identitas lain apapun yang dimilikinya seperti identitas agama, etnis, daerah dan lain-lain (Bagir, 2011:17). Terlepas dari identitas rasial dan fisikal yang dimiliki sejak lahir serta identitas agama yang sifatnya generatif terdapat juga suatu imaji tentang kehidupan bersama dalam ruang Negara.

Berangkat dari kekhawatiran Tilaar (2007) mengenai peliknya perumusan identitas nasional, karena bangsa indonesia dihadapkan pada kompleksitas permasalahan. Pertama, masih kuatnya identitas primodial yang pada satu sisi mempererat solidaritas sosial kesukuan yang ditandai dengan kesamaan bahasa, adat, daerah tempat kelahiran, dipihak lain dapat membenturkan dengan identitas antar suku lain, sehingga dapat terjadi ketegangan identitas, konflik horizontal, dan kekerasan yang kemudian dirumuskan oleh Liliweri (2009) sebagai prasangka antar etnik. Prasangka mengandung tiga tipe, pertama afektif (perasaan yang tidak nyaman terhadap keberadaan etnik tertentu), kedua kognitif (selalu berfikir strereotip tentang etnik tertentu), terakhir behavioral (berupa tindakan diskriminatif terhadap etnik tertentu) (Liliweri, 2009:203). Permasalahan kedua, tidak meratanya pertubuhan ekonomi di wilayah tertentu dibandingkan dengan wilayah lain, menyebabkan adanya wilayah tertinggal yang jauh dari sentuhan modernisasi atau terbentuk suatu bangunan kognitif yaitu wilayah pusat dan wilayah pinggiran (Wallerstein dalam Sanderson, 2011:392). Sehinggal hal tersebut menurut Salim (2014) dapat terbentuk identitas eksklusif dan tidak mengakui keberadaan negara karena merasa terdiskriminasi.

Pandangan merasa terdiskriminasi akan melahirkan anggapan bahwa mereka berbeda dengan kita karena itu kita tidak sama dengan mereka. Terlebih adanya perbedaan dari sisi fisik sehingga dapat menyebabkan kekerasan rasial. Kekerasan ekonomi ditambah dengan kekerasan rasial semakin mengakumulasi atau menegaskan rasa terdiskriminasi dan berbeda. Ketiga, masuknya Indonesia sebagai sebuah ko- 
muntias global mengakibatnya aktivitas transnasional yang memadat yaitu berupa masuknya budaya luar ke dalam negeri semakin mudah dikonsumsi. Sehingga terjadi redefinisi terhadap keberadaan diri secara simultan. Konteks kultur yang sudah majemuk di dalam negeri, diakumulasikan kembali oleh kultur global yang lebih progresif dan cair. Meminjam gagasan Giddens (2005) manusia dalam mendefinisikan diri selalu akan melakukan monitoring tindakan reflektif. Mendefiniskan identitas diri melalui penataan kembali untuk menyelaraskan pengetahuan mengenai identitas diri dengan konteks diri terkini sebagai sebuah kebutuhan berlanjut.

Mendefinisikan siapa sesungguhnya diri tidak lagi bertumpu pada refrensi lokal, tetapi telah bercampur dengan budaya luar yang masuk ke dalam negeri, maka tepat pandangan Woodward (dalam Putranto, 2016: 106) identitas dibentuk oleh budaya. Kerumitan-kerumitan dalam mencari dan membentuk identitas bangsa, karena banyaknya perbedaan yang dimiliki yang menjadi penghalang tebal bagi penyatuan setiap elemen perbedaan. Dalam menyatukan perbedaan penting untuk dibangun imajenasi kepada seluruh elemen bangsa untuk menumbuhkan rasa bersatu, saling menghormati, menghargai akan perbedaan atau menjadi audensi antara identitas dan perbedaan maka konsep Pancasila dan Bhineka Tunggal Ika dapat terus diproduksi. Suatu falsafah bangsa yang menekankan perhormatan terhadap adanya perbedaan dari sisi bahasa, suku, kultur, yang berbeda namun tetap dalam satu ikatan imajener yaitu bangsa Indonesia.

Nilai-nilai bhineka tunggal ika tumbuh dan berkembang dalam sejarah bangsa mengingat Indonesia yang terbagi atas tujuh belas ribu pulau yang ditempati oleh berbagai suku bangsa. Slogan ini juga merupakan suatu langkah reprentif untuk menanggulangi berbagai tindak diskriminasi atas nama mayoritas. Mayoritas terkadang merasa berkuasa dan memiliki privilese dibanding mereka yang minor secara kuantitas (Lubis, 2015:173). Maka gagasan yang tumbuh dari teks keagamaan Hindu-Budha yaitu bhineka tunggal ika sesuai dengan pendapat Lubis (2015) mengenai politik multikultural. Politik multikultural yaitu pertama, sebagai suatu upaya mem- berikan ruang bagi identitas yang berbeda, kedua upaya penyuaraan dan perjuangan terhadap hak-hak kelompok minoritas, ketiga persamaan hak yang didasarkan atas hak asasi manusia.

Seluruh bangsa terlepas dari identitas dan perbedaan ruang yang ditempatinya adalah sama, setara, dihargai, dihormati, diberikan ruang ekspresi sehingga terbentuk solidaritas sosial ditengah individualitas yang menjadi ciri modernitas. Dalam paradigma Bhineka tunggal ika bangsa Indonesia selain bangsa yang plural juga bangsa yang multikultural. Apabila disimak penjelasan mengenai bhineka tunggal ika menarik disampaikan gagasan Bagir (2011:20) negara bersifat mengatasi setiap kelompok dengan segala kebutuhan dan kepentingannya serta mengatur dan membuat regulasi untuk menciptakan harmoni. Bhineka tunggal ika memiliki peran kontruktif bahkan regulatif dalam melakukan suatu audensi terhadap identitas dan perbedaan di Indonesia, sehingga tercipta iklim masyarakat harmonis dan tertib.

\subsection{Konstruksi Politik Identitas Ruang Ketiga}

Indonesia sebagaimana fakta dilapangan merupakan wilayah yang terbentang oleh pulau-pulau dan dipisahkan oleh lautan. Faktual tersebut berimplikasi kepada wilayah yang luas, dan keadaan ekologis yang sama sekali berbeda. Hal tersebut juga mengakibatkan Indonesia merupakan wilayah yang majemuk, memiliki Identitas yang berbeda, baik dari sisi fisikal, finansial dan kutural. Identitas sebagaimana dikenal sebagai berbagai pernik dalam mengenal, mengetahui dan membedakan seseorang atau sekelompok orang tidak hanya persoalan soiso-psikologis namun juga terdapat ranah politis. Identitas dalam konteks kehidupan berbangsa yang majemuk baik suku, ras, agama dan kultur membutuhkan regulasi untuk merangkum kebhinekaan bangsa, dengan tujuan politis yaitu keharmonisan dan ketertiban, dalam hal ini identitas juga dipengaruhi oleh ruang dan kebudayaan.

Ruang atau arena dalam hal ini adalah Indonesia, kini tidak lagi dan memang dalam lintas sejarah tidak pernah menjadi ruang tertutup. Terdapat berbagai pola interaksi budaya yang terjadi, terkadang antara satu kultur dan yang lain saling 
melakukan adaptasi, tidak jarang juga terjadi kontestasi. Kultur atau tradisi dianggap luhur karena berasal dari dalam negeri dan budaya akar rumput diwakili oleh sikap mengutamakan komunalitas, kedaerahan, solidaritas tinggi, mencintai seni, dan religiusitas. Dilain pihak globalisasi menginginkan suatu perubahan progresif ke arah kemajuan, individualitas, intelektualitas, sekuleritas. Akomodasi antara keduanya juga sering diajukan, dengan konsep glokalisasi, berfikir global bertindak lokal. Antara tradisional, global, dan persatuan keduanya seakan menunjukan diri di ruang publik melalui berbagai wacana dan menjadi solusi bagi kehidupan masa kini. Tidak jarang antara satu dan yang lain saling me-mitos-kan. Kultur global menganggap tradisi adalah barang antik, kuno dan mitos sehingga harus ditinggalkan, kultur tradisional berargumen globalisasi suatu penyesatan, post-realitas, kehidupan penuh ekstasi, banal.

Kontestasi tersebut telah diramalkan oleh Huntington (2002) melalui enam premis dasar mengenai konstelasi politik Dunia.

Pertama, perbedaan di antara peradaban tidak hanya nyata, tetapi sangat mendasar. Kedua dunia semakin mengecil, interaksi diantara masyarakat dan peradaban yang berbeda terus meningkat. Ketiga proses modernisasi ekonomi dan perubahan sosial diseluruh Dunia telah mengakibatkan tercerabutnya masyarakat seluruh dunia dari akar-akar identitas-identitas lokal yang berlangsung lama, keempat semakin berkembangnya kesadaran peradaban akibat peran ganda dunia barat. Kelima karakteristik dan perbedaan kultural yang terjadi antara peradaban barat dan non-barat semakin mengeras. Keenam, regionalisme ekonomi semakin mengeras (Huntington, 2002: ix-x).

Identitas yang dibentuk oleh kultur lokal, yang telah lama dan mapan mengalami gugatan serta ketegangan akibat dari dunia yang semakin mengecil, interaksi masyarakat yang dibatasi oleh ruang dan waktu mulai melonggar bahkan mencair. Kesadaran menjadi manusia global dengan gaung teknologi dan kemajuan IPTEK membuat masyarakat mempertanyakan identitas lokalnya. Keadaan gesekan antara nilai-nilai yang mapan dengan nilai-nilai baru yang muncul dan diterima sebagai sebuah keharusan dalam perubahan sosial akan menimbulkan anomali. Adaptasi kultural sebagai suatu respon kultural terhadap perubahan sosial dalam masyarakat dijadikan suatu modus untuk menghadapi tantangan global. Dengan merumuskan pemikiran K. Bhaba, menarik disampaikan gagasan Supriyono (2015) mengenai identitas ruang ketiga.

Menunjuk pada iklim dunia modern yang menyerupai jejaring kebudayaan yang sangat kompleks dan rumit disertai lintas informasi yang kian hari kian cepat, tidaklah bijak kalau identitas Indonesia hendak kita rumuskan dari masa lalu, tetapi hal ini tidak berarti pula sebaliknya bergerak ekstrim menuju kosmopolitan. Saran saya adalah membiarkan Indonesia selalu berada dalam proses persilangan akibat perjumpaan dengan budaya-budaya lain yang tidak terhindarkan (Supriyono, 2015:151).

Perumusan identitas tidak pernah lepas dari persilangan budaya, identitas Bali, Jawa, Sumatra, Sulawesi yang dikenal tidak hanya atas dasar dominasi satu budaya yang cenderung mentotalisasikan bahkan menghapuskan budaya lain. Selalu ada strategi adaptasi budaya dalam perumusan identitas yang tidak pernah selesai. Supremasi satu kelompok budaya dan menghilangkan, menegasi, mentotalkan, mendisfungsionalkan budaya lain, akan menimbulkan fundamentalisme, eksklusivitas yang berujung ekstrimisme, atau perang identitas. Jadi sesuai asumsi teori liminitas Homi K. Bhaba, biarkan wacana identitas mengalir diruang publik sehingga identitas Indonesia berada dalam ruang talik-ulur yang bergerak.

\section{PENUTUP}

\section{Simpulan}

Dari gambaran di atas, dapat disimpulkan bahwa konstruksi Identitas dalam dualisme kutural sebagai ciri zaman global, terus diwacanakan di ruang publik. Zaman global dengan ciri dualisme kultural selalu mensyaratkan adanya pertentangan antara dua hal yang berbeda yaitu anatar pusat-pinggiran, substanti-marginal, spiritual-banal ritual. Dualisme tersebut mengakibatkan adanya usaha terhadap politik Identitas dalam merumuskan ke-indonesiaan yaitu peran 
Pancasila sebagai audensi antara identitas daerah dan perbedaan yang ada dalam tubuh negara-bangsa Indonesia, serta kontruksi identitas ruang ketiga sebagai sebuah identitas yang cair.

\section{DAFTAR PUSTAKA}

Abdullah, Irwan. 2009. Konstruksi dan Reproduksi Kebudayaan. Yogyakarta: Pustaka Pelajar.

Adimihardja, Kusnaka. 2008. Dinamika Budaya Lokal. Bandung: Kerjasama CV Indra Prahasta dengan Pusat Kajian LBPB.

Atmadja, Nengah Bawa. 2010. "Lulus d Jadi PRT dan Dakocan Perspektif Dualisme Kultural". dalM harian Bali Post edisi Sabtu 17 Juli 2010.

Bagir, Zainal Abidin. 2011. Pluralisme, Keragaman, Arah baru Politik Keragaman di Indonesia. Yogyakarta: Mizan dan CRCS.

Giddens, Anthony. 2005. Konsekuensi-Konsekuensi Modernitas. Yogyakarta: Kreasi Wacana.

Hardiman, F. Budi. 2016. Melampaui Positivisme dan Modernitas. Yogyakarta: Kanisius (Anggota IKAPI).

Huntington, Samuel P. 2002. Benturan Antar Peradaban. Yogyakarta: Qalam.

Liliweri, Alo. 2009. Prasangka dan Konflik: Komunikasi Lintas Budaya Masyarakat Multikultur. Yogyakarta: LKis.
Lubis, Akhyar Yusuf. 2015. Pemikiran Kritis Kontemporer. Jakarta: Rajawali Press.

Martono, Nanang. 2016. Sosiologi Perubahan Sosial. Jakarta: Rajawali Press.

Nugroho, Heru. 2001. Negara, Pasar dan Keadilan Sosial. Yogyakarta: Pustaka Pelajar.

Putranto, Hendar. 2016. Ideologi Pancasila Berbasis Multikulturalisme Sebuah Pengantar. Jakarta: Mitra Wacana Media.

Said, Edward W. 2006. Orientalisme. Yogyakarta: Pustaka Pelajar.

Sanderson, Stephen K. 2011. Makrososiologi. Jakarta: Rajawali Pres.

Salim, Agus. 2014. Perubahan Sosial. Yogyakarta: Tiara Wacana.

Supriyono, J. 2015. Mencari Identitas Kutur Keindonesiaan. dalam "Hermeneutika Pasca Kolonial: Soal Identitas" (Mudju Sutrisno dan Hendar Putranto: editor). Yogyakarta: Kanisius.

Sutrisno, Mudji. 2015. Rumitnya Pencarian Diri Kultural. dalam "Hermeneutika Pasca Kolonial: Soal Identitas" (Mudju Sutrisno dan Hendar Putranto: editor). Yogyakarta: Kanisius.

Tilaar, H.A.R. 2007. Mengindonesiakan Etnisitas dan Identitas Bangsa Indonesia: Tinjauan dari Perspektif Pendidikan. Jakarta: Rineka Cipta. 